Please cite as: B. Braun, 'Central bank planning: Unconventional monetary policy and the price of bending the yield curve.' In Uncertain Futures: Imaginaries, Narratives, and Calculation in the Economy, edited by J. Beckert and R. Bronk. Oxford: Oxford University Press, 194-216.

Pre-print version (January 2018)

\title{
Central Bank Planning: Unconventional Monetary Policy and the Price of Bending the Yield Curve
}

\author{
Benjamin Braun \\ Max Planck Institute for the Study of Societies \\ bb@mpifg.de
}

\begin{abstract}
Central banks have increasingly used communication to guide market actors' expectations of future rates of interest, inflation, and growth. However, aware of the pitfalls of (financial) central planning, central bankers until recently drew a line by restricting their monetary policy interventions to short-term interest rates. Longer-term rates, they argued, reflected decentralised knowledge and should be determined by market forces. By embracing forward guidance and quantitative easing (QE) to target long-term rates, central banks have crossed that line. While consistent with the post1980 expansion of the temporal reach of monetary policy further into the future, these unconventional policies nevertheless mark a structural break - the return of hydraulic macroeconomic state agency, refashioned for a financialised economy. This chapter analyses the theoretical and practical reasoning behind this shift in governability paradigm, and examines the epistemic and reputational costs of modern central bank planning and the non-market setting of long-term bond prices.
\end{abstract}

Keywords: Quantitative easing, forward guidance, ECB, expectations, performativity, governability paradigm, epistemic authority.

JEL classification: $\mathrm{E}_{43}, \mathrm{E}_{5} 8, \mathrm{~F} 59, \mathrm{P}_{11}, \mathrm{Z}_{13}$

Acknowledgements: This chapter has benefitted from the comments of Jens Beckert, Richard Bronk, Peter Dietsch, Maximilian Düsterhöft, Dirk Ehnts, Onur Ozgode, Waltraud Schelkle, and Matthew Watson. Any errors are mine. 
[I]t is absurd to think of a purely 'objective' prediction. Anybody who makes a prediction has in fact a 'programme' for whose victory he is working, and his prediction is precisely an element contributing to that victory.

(Gramsci 1971, 171)

\section{Introduction}

This volume examines a contradiction at the heart of economic action. While economic action is necessarily future-oriented, the future is characterized by Knightean uncertainty-that is, it cannot be known. In order to avoid paralysis, economic agents imagine futures that enable them to take decisions in the present 'despite the incalculability of outcomes' (Beckert 2016, 9). From a macroeconomic perspective, this tension is compounded by the problem of order and stability, which requires that economic actors' beliefs and actions be coordinated despite uncertainty. In theory, there are two 'pure' solutions to this coordination problem. It can be solved: (i) in a centralized fashion by a social planner dedicated to eliminating uncertainty; or (ii) by Hayekian speculators whose decentralized beliefs and actions are coordinated via market pricing (Konings 2016, 278). In practice, pragmatic solutions prevail; central institutions 'reduce' uncertainty while leaving the price mechanism largely intact. This chapter focusses on a particularly consequential coordination-facilitating institution, central banking. A carefully calibrated configuration of technocrats, laws, and technologies, this apparatus is geared towards producing a specific 'genre' of imagined futures-expectations-and towards getting economic units to internalize and coordinate their actions around those expectations.

Although the distributional consequences of central banking are beyond the scope of this chapter (see Fontan et al. 2016), they motivate and justify the following exploration of the linkages between economic theories, governance practices, and imagined futures (or expectations). Central bank expectation management is consequential because it affects macroeconomic outcomes, often in unintended ways. On one hand, modern monetary governance is built on the premise that central bank guidance on expectations-notwithstanding the occasional blipenhances economic efficiency and stability. On the other hand, in a world of Knightean uncertainty the issuers of such guidance are prone to punching above their (epistemic) weight. Indeed, it is difficult to distinguish, ex ante, between wise coordination of expectations and the overconfident orchestration of groupthink and herding. There is a long line-from Milton Friedman to John Taylor-of conservative critics of discretionary monetary fine-tuning who have argued that 'active policy is as likely to amplify as offset the effects of shocks upon the macroeconomy' (Haldane 1995, 6). If that argument has merit-and recent history suggests it does-what Hayek (1989) dubs the 'pretence of knowledge' is not an occasional but rather a widespread feature of 'governing through expectations' in conditions of uncertainty (Braun 2015).

After a decade of aggressive interventionism by the world's leading central banks, calls for caution have recently grown louder. One increasingly vocal critic, the Bank for International Settlements (BIS), has urged central banks to show a keener appreciation of the cumulative impact of policies on the stocks of debt, on the allocation of resources and on the room for policy manoeuvre' (BIS 2016, 8). This chapter contributes to the growing literature on how and why macroeconomic governance oscillates between intended counter-cyclical stabilization and 
unintended pro-cyclical amplification of the boom and bust dynamic of the business cycle (Baker and Widmaier 2014; Braun 2014; Bronk and Jacoby 2016; Golub et al. 2015; Widmaier 2016).

The chapter advances three main arguments:

(i) 'Keynesian' fiscal demand management and monetary inflation targeting can be conceptualized as separate ideal-types of macroeconomic state agency: the former operates in a hydraulic manner, while the latter is strategic and performative. Crucially, however, recent quantitative easing programmes mark a return to the hydraulic style of macroeconomic governance, albeit via the monetary rather than the fiscal authority, and via the market for financial assets rather than the markets for goods and services.

(ii) The chapter proposes a reading of the past three decades of central bank history as a quest to expand the temporal reach of monetary policy into the future. A structural break occurred when central banks shifted from open market operations at the short end of the yield curve to purchases of longer-dated securities. ${ }^{1}$ In the guise of balance sheet policy, central banking has-this chapter argues-morphed into a form of central (bank) planning.

(iii) While this transition has much to do with the practical challenges of monetary policy implementation and transmission, central bank planning also has an important theoretical lineage in macroeconomics. Building on the literature on the performative effects of economic models and central bank communication in 'making' the economy (Christophers 2017; Holmes 2014), but moving towards an understanding more akin to Mitchell (2005) and MacKenzie (2006), this chapter reveals a deeper connection between general-equilibrium theory in macroeconomics and central bank planning. ${ }^{2}$

\section{Governability Paradigms: Fiscal Demand Management vs. Monetary Inflation Targeting}

Why is it that the economy is governable by means of monetary policy? Contrary to the widespread notion of all-powerful central banks, the effectiveness of monetary policy has always been fragile, both in theory and in practice. While the New Classical view that the economy was essentially ungovernable and that government intervention would, at best, be ineffective was suppressed by the new neoclassical synthesis (Braun 2014, 61), doubts regarding the effectiveness of monetary policy never went away. It has, for instance, long been the 'prevailing view' in central banking circles that 'over the medium term, monetary policy only passively tracks the natural [interest] rate' (Juselius et al. 2016, 1). More recently, evidence for the 'globalization of inflation' has called into question the very notion-foundational for contemporary monetary policy-of inflation as a domestic phenomenon (Auer et al. 2017).

In light of these observations, this chapter conceptualizes macroeconomic governability as the unstable effect of historically contingent configurations of institutions, theories, and governance practices (Braun 2014). A governability paradigm is established when a political consensus on

\footnotetext{
${ }^{1}$ The 'yield curve' is a visual representation of the relationship between the residual maturity of a debt security and its 'yield' or interest rate (see Figure 1).

${ }^{2}$ For an argument about how the work of MacKenzie (and Michel Callon) can improve the micro-foundations of political economy more generally, see Braun (2016a).
} 
macroeconomic policies (Hall 1993) is reinforced by an academic consensus on macroeconomic theories. In the brief history of modern macroeconomics, these two things have come together only twice: in the form of 'Keynesian' fiscal demand management, underpinned by the neoclassical synthesis, and in the form of monetary inflation targeting underpinned by the 'new neoclassical synthesis' (Braun 2014; Widmaier 2016). These governability paradigms were embedded in two distinct regimes. During the Bretton Woods era of restricted international capital flows and highly regulated financial systems, macroeconomic governance operated through price and interest rate controls and direct fiscal spending. In the context of financial deregulation and financialization, the headquarters of macroeconomic governance shifted from the fiscal authority to the monetary authority.

Paving the conceptual way for the remainder of the chapter, this section compares the two paradigms in terms of the 'four T's' of macroeconomic state agency: transmission, temporality, transparency, and theory (see Table 1).

Table 1: The 'four T's' of macroeconomic state agency-two governability paradigms compared

\begin{tabular}{l|l|l|l}
\hline & $\begin{array}{l}\text { 'Keynesian' fiscal demand } \\
\text { management }\end{array}$ & $\begin{array}{l}\text { Transition-period } \\
\text { monetary policy }\end{array}$ & Monetary inflation targeting \\
\hline Transmission & Centralized and direct & & Decentralized and indirect \\
\hline Temporality & Present-oriented & Future-oriented \\
\hline Transparency & Opacity & Secrecy & Transparency \\
\hline Theory & \multicolumn{2}{|c}{$\begin{array}{r}\text { Hydraulic/optimal control: } \\
\text { game against nature }\end{array}$} & $\begin{array}{l}\text { Communicative/performative: } \\
\text { game with rational agents }\end{array}$ \\
\hline
\end{tabular}

\section{Transmission}

Fiscal demand management influences the economy by increasing or decreasing demand directly through centralized government expenditure. Although 'animal spirits' and a 'multiplier effect' are important aspects, fiscal demand management operates through interventions that have sizeable first-round effects in the markets for labour, goods, and services (the 'real economy'). By contrast, inflation-targeting central banks typically rely on open market operations that have only small first-round effects in a small sector of the financial economy, the interbank money market. A gap therefore exists between the operational target of monetary policy-the short-term interbank interest rate-and the long-term interest rates that matter most for the actual targets of monetary policy, namely, investment, output, employment, and, ultimately, inflation. To bridge this gap, central bankers rely on the 'transmission mechanism of monetary policy'. Generally thought of as comprising a bank lending channel, a bank capital channel, a balance sheet channel (or 'financial accelerator'), and, more recently, a separate risk-taking channel (Borio and Zhu 2012), the transmission mechanism is indirect, decentralized, and prone to disruption. It also relies heavily on expectations. 


\section{Temporality}

In principle, a Keynesian fiscal stimulus works best in a world in which consumers' spending decisions are unencumbered by expectations of higher future taxes. By contrast, the future intentionally looms large under inflation targeting, for both theoretical and practical reasons. Theoretically, rational-expectations macroeconomics pushed the focal point for macroeconomic coordination into the future by arguing that short-term stabilization measures would be neutralized by rational actors anticipating and discounting the long-term consequences (Lucas and Sargent 1979). The practical reason has to do with the expectational dimension of monetary policy's transmission mechanism. The impact of a change in the short-term interest rate today depends on how it affects private sector expectations of inflation and interest rates tomorrow. If market expectations fail to adjust, the interest-rate change will be ineffectual. As the leading monetary theorist put it in the heyday of inflation targeting, '[n]ot only do expectations about policy matter, but, at least under current conditions, very little else matters' (Woodford 2003, 15). This has direct implications for the third ' $T$ '.

\section{Transparency}

Anthony Giddens once suggested that Keynesian demand management could perhaps 'only be effective in circumstances in which the majority of the population, or certain key sets of business actors, do not know what Keynesianism is' (Giddens 1987, 201). He shared this view with the New Classical economists, who saw non-transparency as a necessary feature of countercyclical policies. According to them, the effectiveness of such policies 'rests on the inability of private agents to recognize systematic patterns in monetary and fiscal policy' (Lucas and Sargent 1979, 58 ); that is, their inability to understand the (New Classical) concepts of Ricardian equivalence or the neutrality of money. When monetary policy assumed a larger share of the burden of macroeconomic stabilization policy during the late 1970 s and the 1980 -a transitional period between two governability paradigms-it continued to operate on the principles of obscurity and secrecy (Goodfriend, 1986). Little changed until the early 1990s (Haldane 2017, 5). Only when inflation targeting gained traction did central banks shift from secrecy to 'strategic transparency' (Abolafia and Hatmaker 2013, 541-543; Krippner 2007). The more predictable the central bank, the argument went, the more predictable-and hence governable-the behaviour of market actors. This comparison of the two governability paradigms in terms of transmission, temporality, and transparency, sets the scene for a discussion of the fourth ' $\mathrm{T}$ '-theory-and thus of the deep performativity of central banking. ${ }^{3}$

\footnotetext{
3 For a study of deep performativity in the area of fiscal policy, see Heimberger and Kapeller (2017).
} 


\section{Deep Performativity: Uncertainty, Rational Expectations, and Central Bank Planning}

At the heart of rational expectations macroeconomics lies a paradox. While real-business-cycle and dynamic-stochastic general equilibrium (DSGE) models are populated by competing and unflinchingly rational maximizers, the theoretical innovation that brought them about carried the seeds of central (bank) planning. John Muth and Robert Lucas introduced the rational expectations hypothesis (REH) as a modelling assumption, defining rational expectations as 'essentially the same as the predictions of the relevant economic theory' (Muth 1961, 316). While not making a normative statement about 'what firms ought to do' (Muth 1961, 316), they did make a normative statement about what economists ought to do; namely, assume that the prediction of their model was the point around which firms' expectations were (normally) distributed. That makes the world of rational expectations a world of Knightean 'risk' rather than uncertainty. In real-business-cycle and DSGE models, all agents-that is, the 'representative agent'-use the 'true' model (that is, the modelling economist's model) to predict correctly (the probabilities of) all possible future prices and outcomes (Frydman and Goldberg 2011, 62).

The REH has two implications that bear on the theory of central planning. ${ }^{4}$ First, while different economists may build different models, within each model there is what Thomas Sargent (Evans and Honkapohja 2005, 566) called 'a communism of models', whereby '[a]ll agents inside the model, the econometrician, and God share the same model'. Second, the assumed omniscience of rational expectations macroeconomics runs counter to the Hayekian case for the market mechanism (Bronk 2013; Hayek 1945). In a world in which all agents share the same (correct) economic model, centralized knowledge is just as good as decentralized knowledge. As a result, 'there would be no need for markets to set prices ... [a]ll economists and each rational market participant would be capable of accomplishing this feat entirely on their own' (Frydman and Goldberg 2011, 66). This section discusses how these theoretical implications of the REH relate to the practice of central banking.

\section{'Communism of Models' and Epistemic Authority}

In the real world, reducing uncertainty about the 'correct' model of the economy is a key element of coordinating private-sector expectations (Nelson and Katzenstein 2014). Central banks have used REH-based models as narrative and coordinative devices for precisely this purpose (Beckert 2016; Holmes 2014). The central banks that pioneered inflation-forecast targeting were the first to incorporate DSGE models-the model-version of the new neoclassical synthesis-into their apparatuses of expectation management. When the central banks of Canada and New Zealand introduced the precursors of today's DSGE models, these 'were not mere research projects, but models used for practical policy deliberations under the 'forecast targeting' approach to monetary policy' (Woodford 2009, 276; see also Holmes 2014, 92-97). By the time the financial crisis hit, most leading central banks relied heavily on DSGE models, which largely abstracted from the

\footnotetext{
${ }_{4}^{4} \mathrm{~A}$ close affinity exists between general equilibrium theory and socialist planning that precedes the advent of REH-based
} macroeconomics; see Mirowski (2002) and Boldyrev and Kirtchik (2017). 
financial sector, creating a dangerous 'modelling monoculture' (Bronk 2011; Bronk and Jacoby 2016). Sargent's 'communism of models' had become a reality.

Maintaining this model communism in academic and financial circles requires a type of credibility that differs from the conventional concept of credibility that, in reaction to the REHinspired time-inconsistency critique, became the holy grail of central banking (Barro and Gordon 1983; Kydland and Prescott 1977). According to this literature, a central bank can acquire credibility on the basis of a historical record of high inflation aversion, because it is "bound by a rule or other "commitment technology", or because senior central bankers are employed on an 'incentive-compatible contract' (Blinder 2000, 1423). In Blinder's own definition (2000, 1423), 'a central bank is credible if people believe it will do what it says'. In practice, this is the credibility of the central bank's commitment to raise the policy rate when the (expected) inflation rate goes up. In the presence of 'epistemic uncertainty' (Nelson and Katzenstein 2014, 363), however, central banks seek not only commitment credibility but also forecasting credibility-or, to use an established term, epistemic authority (Rosenhek 2013). Paraphrasing Blinder's definition, a central bank enjoys epistemic authority if people believe its forecasts.

Market actors may decide to form their own expectations on the basis of a central bank forecast because they believe that it provides the best prediction of economic fundamentals, and/or that it will serve as a focal point for the coordination of private-sector expectations (Morris and Shin 2002, 1522). In either case, epistemic authority is fragile. In order to bolster it, central banks have invested heavily in the scientization of monetary policy. Increasing the ranks of PhD-level economists both at the staff level and in leadership positions, central banks have effectively transformed themselves into research hubs of unprecedented size and scope (Conti-Brown 2016, 90-93; Marcussen 2009; Mudge and Vauchez 2016). Leadership positions are routinely assigned to academic economists, including Stanley Fischer, Mervyn King, Ben Bernanke, Raghuram Rajan, and Janet Yellen. Regardless of the scientific rigour it may or may not bring to the policy process, scientization has a performative dimension. Models and academic merits are props in a carefully staged performance of competence and knowledge that bolsters the uncertaintyreducing effect of central bank forecasts (Goffman 1959). It is impossible to determine, in real time, where knowledge ends and where what Hayek called 'pretence of knowledge' begins (Hayek 1989). Following the financial crisis, some macroeconomists decried a pervasive 'pretense-ofknowledge syndrome' in their discipline (Caballero 2010). However, under conditions of uncertainty, the 'pretention that the fictional depictions [are] indeed true representations of the future' (Beckert 2013b, 226) is part and parcel of economic decision-making. From this perspective, 'pretence of knowledge' is not pathological, as Hayek and Caballero argue, but performs a productive-albeit problematic-function in the communicative apparatus of monetary expectation management (Braun 2015).

Targeting long-term interest rates through the twin policies of forward guidance and quantitative easing, central banks have recently extended their reach into much more distant futures. As the section 'Long-term Interest Rates as Policy Variables: Post-crisis Central Bank Planning' will demonstrate for the case of the European Central Bank (ECB), this has made it harder to maintain the pretence of superior central bank knowledge. The attempt to bolster the credibility 
of its commitment to stabilize inflation at a low but positive rate has, this chapter will argue, undermined the ECB's claim to epistemic authority.

\section{Non-market Price Setting: From Hydraulic to Performative Governability, and Back Again}

The quasi-mechanical connection between government spending and aggregate demand-the economic agency of the Keynesian state-can be conceptualized as hydraulic (Braun 2014, 59; Pahl and Sparsam 2016). Central bank agency under inflation targeting, by contrast, has been described as communicative and performative: central bankers' utterances 'are making the economy ... as a communicative field and as an empirical fact' (Holmes 2014, 12; see also Krippner 2007). However, these utterances refer to an 'economy' that has a prior existence as a theoretical fact. The performative nature of inflation targeting comes into full view only if the performative dimension of REH theory-based macroeconomics-namely, its unexpectedly ambiguous relationship with 'the economy' and its inbuilt performativity-is explained.

Lucas and others argued that Keynesian macroeconomics assumed, wrongly, that modelling the economy and governing the economy were two different things, and that the economy was a mechanical system of aggregates that followed a set of quasi-physical laws (Lucas and Sargent 1979, 12). Interestingly, this 'optimal control' mind-set still underpinned monetary policy during the transitional Volcker and (early) Greenspan era: 'A set of equations described the behavior of the private sector; the job of the central bank was to select the proper settings for its policy instruments to guide the economy along its optimal path' (Poole and Rasche 2000, 257). Over the long term, however, rational expectations proved to be a game changer. As Kydland and Prescott $(1977,473)$ put it in their influential article on policy ineffectiveness, 'economic planning is not a game against nature but, rather, a game against rational economic agents'. New Classical theorists, who dismissed Keynesians for modelling macroeconomic aggregates, aimed at putting macroeconomics on 'microfoundations'-'representative' households and firms that rationally maximize objective functions and adapt instantly to policy changes. This made the new 'game against rational economic agents' trickier than the old 'game against nature'. The predictability of a mechanical system had been replaced by the strategic calculations of homo oeconomicus, which tended to neutralize or counteract countercyclical policy interventions: 'The private sector could in principle not be modelled without specifying the monetary policy rule, because the behaviour of optimizing agents could not be predicted without modelling their expectations about monetary policy' (Poole and Rasche 2000, 257). Thus, by substituting reflexivity for optimal control, Lucas and colleagues unwittingly brought performativity to monetary policy-long before central bankers became expectation managers.

Somewhat ironically, rational expectations theorists only saw the downside for governability. It was for monetary policy-makers to discover that the 'game against rational agents' could be turned into a 'game with rational agents'. When central bankers realized that control over the economy depended on their ability to harness market actors' expectations, they transformed macroeconomic governance from an 'engineering' problem into a 'strategic' one (Morris and Shin 2008, 88). The notion of a hydraulic system that could be manipulated by skilled engineers was replaced by the performative challenge of making market expectations conform to the rationality standards as defined by those who hoped to govern through these expectations. 
Here, too, central banks' responses to the financial crisis marked a turning point. Historically, central banks fixed the price for short-term liquidity in the interbank market. With the shift from conventional interest-rate policy to unconventional balance-sheet policy, however, central banks expanded their reach to security prices at the long end of the yield curve. Expanding the government's (consolidated) balance sheet to purchase securities-rather than goods and services, as fiscal policy would-central banks effectively returned to a hydraulic mode of economic governance. Focussing on the euro area, the remainder of this chapter will further examine these reversals: the revival of hydraulic macroeconomic policy and the undermining of epistemic authority.

\section{Forward Guidance and QE in the Euro Area}

At various points after 2008, the Fed, the ECB, the Bank of England, and the Bank of Japan all adopted two types of 'unconventional' monetary policies to stabilize financial conditions and stimulate economic activity: forward guidance and large-scale asset purchases, or quantitative easing. These policies are complementary in that both aim explicitly at lowering long-term interest rates when the short-term rate is already at the effective lower bound (Couré 2015, 2). However, whereas forward guidance-an advanced version of expectation management-is consistent with conventional 'interest rate policy', asset purchases fall into the economically distinct category of 'balance sheet policy' (Borio and Disyatat 2009, 1).

\section{Forward Guidance: From Transparency to Commitment}

In light of the long-standing trend for central banks to become more transparent about their actions and intentions, forward guidance embodies continuity rather than change. Smaller central banks, in particular, had long published unconditional forecasts of the future path of their policy rates, thus increasing the reach of their expectation management further into the future (Filardo and Hofmann 2014, 38; Holmes 2014, 77-79). The ECB, too, had been moving towards greater forecast transparency in the early 2000 (Braun 2015, 375-377). However, these 'Delphic' forms of forward guidance did not involve a commitment (Campbell et al. 2012). Commitment to particular courses of action thus was the innovative element of the 'Odyssean' (ibid.) variant of forward guidance that became prevalent after 2008. The rationale was simple: forward guidance would allow policymakers to 'change public expectations of their actions tomorrow in a way that improves macroeconomic performance today' (Campbell et al. 2012, 3). The ECB announced its own version of forward guidance in June 2013:

The Governing Council expects the key ECB interest rates to remain at present or lower levels for an extended period of time. This expectation is based on the overall subdued outlook for inflation extending into the medium term, given the broad-based weakness in the real economy and subdued monetary dynamics.

(Draghi 2013; emphasis added)

Instead of the quantitative, threshold-based forward guidance ultimately embraced by the Fed (FOMC 2013), the ECB thus chose a cautious, open-ended variant. While following its peers in making its forward guidance conditional-most notably on the medium-term inflation outlook- 
the ECB did not commit to maintaining current interest rate levels until a specific date or macroeconomic outcome was reached. In its Monthly Bulletin, the ECB described its own approach as ‘[q]ualitative forward guidance conditional on a narrative’ (ECB 2014, 68).

Notwithstanding the innovative commitment aspects, such forward guidance is-as a purely communicative tool designed to manage expectations-fully consistent with the pre-crisis paradigm of 'discursive central banking' (Gabor and Jessop 2015). The same is not true of quantitative easing, which brings something other than words to the governability table, namely, the central bank balance sheet.

\section{Quantitative Easing}

In order to keep the short-term interbank interest rate aligned with its main refinancing rate, the Eurosystem-the ECB and the national central banks-used to provide precisely that amount of reserves that would satisfy the banking system's liquidity needs, thus keeping supply and demand for reserves in the interbank market in balance. While the Eurosystem conducts collateralized lending operations for this purpose, other central banks, such as the Fed, provide liquidity through open market operations (that is, outright purchases of securities). In purely technical terms, large-scale asset purchases are but an expanded version of the latter, in that the central bank creates new reserves to buy securities in the open market (Couré 2015). In economic terms, however, the two are very different. Conventional open market operations are designed to affect the short-term interest rate via the liability side of the central bank's balance sheet-namely, the amount of reserves provided to the banking system (Friedman 2014, 7). QE open market operations, by contrast, are designed to affect long-term interest rates via the asset side of the central bank's balance sheet-namely, the amount of securities absorbed from the financial system.

Following the example of its peers, the ECB decided to expand its balance sheet by purchasing both government bonds and securities issued by the private sector. In late 2014, a third covered bond purchase programme $\left(\mathrm{CBPP}_{3}\right)$ and an asset-backed securities purchase programme (ABSPP) marked the prelude to the public sector purchase programme (PSPP), which the ECB launched in March 2015. In June 2016, the ECB added the corporate sector purchase programme (CSPP). Together, these various components form the 'expanded asset purchase programme' (APP). At year-end 2016, public sector securities accounted for 82 per cent of Eurosystem holdings under the APP. The weighted average remaining maturity of the ECB's holdings of government bonds is currently 8.3 years, showing that the PSPP targets bonds with mid-range maturities.

The ECB's quantitative easing comes with its own form of forward guidance. The ECB has committed to purchasing securities worth EUR 6o billion every month 'until the end of 2017 and in any case until the Governing Council sees a sustained adjustment in the path of inflation that is consistent with its aim of achieving inflation rates below, but close to, $2 \%$ over the medium term'. ${ }^{5}$ Indeed, it is important to distinguish two channels through which quantitative easing

${ }_{5}^{5}$ https://www.ecb.europa.eu/mopo/implement/omt/html/index.en.html, accessed on 13 April 2017. 
affects asset prices and interest rates (Valiante 2015). First, the mere announcement of asset purchases changes expectations. Based on the expectation of greater scarcity-and therefore higher prices-of bonds in the future, demand should be expected to increase already in the present, pushing prices up and yields down. However, this ex ante and performative signalling effect is entirely dependent on the expectation of the ex post effect of actual central bank purchases, which increase asset scarcity in a mechanical, hydraulic manner. In short, the ex ante performative and the ex post hydraulic effect of the quantitative easing programme are mutually reinforcing and together push bond prices up and (long-term) interest rates down. As the next section (Long-term Interest Rates as Policy Variables: Post-crisis Central Bank Planning) will show, the implications for macroeconomic state agency are profound.

\section{Long-term Interest Rates as Policy Variables: Post-crisis Central Bank Planning}

Despite a long-standing trend for the apparatus of monetary expectation management to reach ever further into the future, forward guidance and QE crossed what central bankers had previously considered a red line. The ECB, which used to implement its monetary policy stance by targeting the price for short-term interbank liquidity, was vocal about the risks of non-market price setting further up the yield curve. As recently as 2008, it explained its "hands-off' approach', by declaring that 'developments in longer-term money market interest rates reflect market forces' and are therefore 'beyond the ECB's direct control' (ECB 2008, 71, 79). Although they knew it was feasible, central bankers considered efforts to control long-term rates undesirable. The chief architect of the ECB's monetary policy strategy used a classic Hayekian argument against non-market price setting, arguing that centrally determined long-term interest rates 'would cease to have their important allocational [sic] function in a market economy by virtue of being relative indicators of scarcity' (Issing 1992, 293). The consensus under the inflation-targeting paradigm that monetary policy should 'lead the market' rather than 'follow' it (Blinder 2004, 66-74) was thus limited to the short end of the yield curve. The view was widely shared among monetary policymakers that minimizing the potentially distorting influence of such leadership required that longer-term interest rates be determined by market forces (Turner 2011, 19). ${ }^{6}$

After 2008, central banks quietly shelved that view. It became the stated goal of ECB policy to encourage 'portfolio shifts into longer maturity assets and a compression of long-term yields' (ECB 2014, 67). Forward guidance and $\mathrm{QE}$ thus marked a significant departure from the inflation-targeting paradigm of the pre-crisis period. The boundary between 'following' and 'leading the market' shifted towards the long-end of the yield curve, and central banks now 'made the long-term interest rate a policy variable' (Turner 2011, 10). Long-term rates, previously regarded as a barometer for market actors' expectations of the future, became a lever for central banks to influence that future.

${ }^{6}$ For an important critique of the 'barometer' conception of long-term rates, see Shin (2017). 


\section{Forward Guidance and the ECB's Epistemic Authority}

Critics of forward guidance warn that a central bank cannot possibly satisfy market actors' 'insatiable' hunger for information (Issing 2014, 10), and that they would need to escalate their commitments to reassure markets that interest rates would remain unchanged even if economic recovery continued. Indeed, modest signs of recovery in the euro area in early 2014 prompted the ECB to specify that the promise to keep its key interest rates 'at present or lower levels' was 'based on an overall subdued outlook for inflation extending into the medium term, given the broad-based weakness of the economy, the high degree of unutilized capacity, and subdued money and credit creation' (ECB 2014, 69). This somewhat convoluted statement was intended to reassure market participants that even stronger than anticipated growth would not precipitate a rate rise as long as inflation expectations remained anchored, the output gap positive, and bank lending slow. Central banks felt compelled to escalate their forward guidance for fear that positive economic data would cause market actors to adjust their expectations of the future path of the short-term interest rate upwards.

Again, the problem is uncertainty. The goal of forward guidance is to reduce market uncertainty about the future path of interest rates and to 'talk down' longer-term rates, thus bending the long end of the yield curve downward. But longer time horizons imply greater forecast uncertainty. Does the ECB have the epistemic authority needed to steer market expectations of such distant futures? Interestingly, the ECB's chief economist addressed precisely this concern at the 2014 session of the annual 'The ECB and its watchers' conference:

Our approach starts from the premise that the central bank doesn't have superior knowledge about how the world works. Nor are we likely to have better forecasting abilities than the majority of observers. So what we can do is to provide an explicit, well-articulated frame of reference for our actions. ... In practical terms, this means that communication revolves around providing a narrative about the economy...

(Praet 2014)

This amounts to a call on market participants to abandon the pretence of superior central bank knowledge that had formed an integral part of the communicative apparatus of expectation management. What is more, Praet was essentially describing forward guidance as an effort to develop persuasive economic narratives. This points to a dilemma that goes beyond epistemic uncertainty over the central bank's macroeconomic model: namely, the possibility that forecasts-regardless of their accuracy-are being used strategically by central bankers. The following quotes illustrate how observers of central banks have reacted to this possibility.

[T] he market knows that central bankers have no superhuman forecasting ability and will tend to view the supposed longer-term forecasts as a version of jawboning, attempts to persuade the market to change its mind for immediate policy purposes. Again there is little empirical evidence that the market responds to such jawboning, and why should it when the central bank is as ignorant of the longer-term future as they are?

(Goodhart 2012)

[A]s implemented thus far it is not clear why anyone should pay much attention to forward guidance as it is, in our view, mostly 'cheap talk'.

(Buiter 2013, 2) 
Anyone who awaits central bank predictions of inflation two years ahead in the hope of finding out how prices are likely to change has not been paying attention. When the European Central Bank sets out its predictions for inflation on Thursday, it will be blind luck if the numbers turn out to be right in $2016 \ldots$ Whether it is right is neither here nor there, though. The forecasts matter for how they are used; if the ECB is to take a big step further into experimental monetary policy, it needs to predict inflation will stay well below target.

(Mackintosh 2014)

These statements suggest that forward guidance has caused central bank watchers to adopt a view of central bank forecasts that is more cynical in the sense that it subscribes to Gramsci's (1971, 171) dictum, cited in the epigraph, that there is no such thing as 'a purely "objective" prediction'. In turn, this highlights a related problem-the time-inconsistency of forward guidance: once the economy improves and inflation rates start rising, central banks with price stability mandates would have a strong incentive to increase interest rates ahead of the schedule they had previously announced (Buiter 2013, 6; Issing 2014, 7; Woodford 2014, 6). The cost of forward guidance is now increasingly clear: central banks have had to mark down their two most jealously guarded assets: their epistemic authority and their commitment credibility.

The case of forward guidance holds an important lesson regarding the production of imagined futures and the coordination of expectations under conditions of uncertainty. Under such conditions, it is not accurate predictions of future states of the world that determine decisions, but rather a political game of negotiation and manipulation of the interpretation of a situation' (Beckert 2013a, 342). From this perspective, the question is not so much why market actors have become more cynical about 'cheap talk' by central banks, but why they have become so only now. Until recently, there was little indication that markets considered central bank forecasts as rhetorical devices designed to manipulate their expectations. That this has recently changed suggests that unconventional monetary policies have been testing the limits of the apparatus of expectation management, and thus of performative macroeconomic governance. The potentially resulting loss of governability has been compensated for, however, by the introduction of balance sheet policy. But while complementary in the goal dimension (lowering long-term interest rates), balance sheet policy is very different from forward guidance when viewed as an instrument.

\section{Non-market Price Setting: The Return of Hydraulic Macroeconomic Governance}

QE differs significantly from forward guidance in its implications for the nature of economic state agency. Consider the following pleas for euro-area QE, the first by a former ECB Executive Board member, the second by the chief European economist of Goldman Sachs:

[I]f central banks really want to change the shape of the yield curve they may have to do more than just talk. ... In other words, if they want to be effective central banks have to put their money, and balance sheets, where their mouths are.

(Bini Smaghi 2013)

If you can retain credibility and confidence, that may be all you have to do; markets will do the heavy lifting for you ... But not all problems can be solved by shifting market expectations and behaviour. Sometimes fundamental changes are needed.

(Huw Pill, quoted in Atkins 2014) 
These statements chime with the 'crisis of discursive central banking' argument (Gabor and Jessop 2015), according to which monetary policy by communication alone has reached the end of the line. Indeed, all leading central banks have concluded that sustained macroeconomic stimulus requires use of the 'consolidated government sector balance sheet' (Borio and Disyatat 2009, 2). While it is commonplace to argue that quantitative easing has an important fiscal dimension, this chapter highlights another striking parallel between state agency under Keynesian fiscal policy and unconventional monetary policy. Keynesian demand management policy involves the government expanding its balance sheet to purchase goods and services in order to stimulate the (real) economy directly; QE involves the central bank expanding its balance sheet to purchase financial assets in order to stimulate the financial economy directly (with an intended second-round stimulus effect for the real economy). In other words, central banking has acquired what had previously been the exclusive domain of fiscal policy-hydraulic macroeconomic agency.

Highlighting the hydraulic transmission mechanism of quantitative easing is not to say that it represents a return to the Keynesian past. On the contrary, QE represents an adaptation of macroeconomic governance to the workings of a financialized economy. Among monetary and financial economists, the idea has recently gained traction that financial market developments have spawned a new transmission channel of monetary policy, the so-called 'risk-taking channel' (Borio and $\mathrm{Zhu}$ 2012). Under this mechanism, changes in interest rates and market expectations about their future path may alter the 'perceptions of risks and risk tolerance' of financial firms (ibid. 237). This channel has gained in importance as a result of 'financial liberalization and innovation', which have increased the responsiveness of credit creation to swings in risk perception, and therefore the impact of the latter on aggregate demand (ibid. 237). The ECB shares this analysis with regard to the monetary transmission mechanism in the euro area (ECB 2010, 85, 89). Under these conditions, QE is supposed to stimulate aggregate demand through the so-called portfolio rebalancing effect (Draghi 2015). As pointed out by ECB Executive Board member Benoît Couré $(2015,2)$, this is due to a quasi-hydraulic mechanism whereby central bank asset purchases 'mechanically reduce the supply of securities'. 
Figure 1: Yield curves for bonds of euro-area governments (all issuers and ratings)

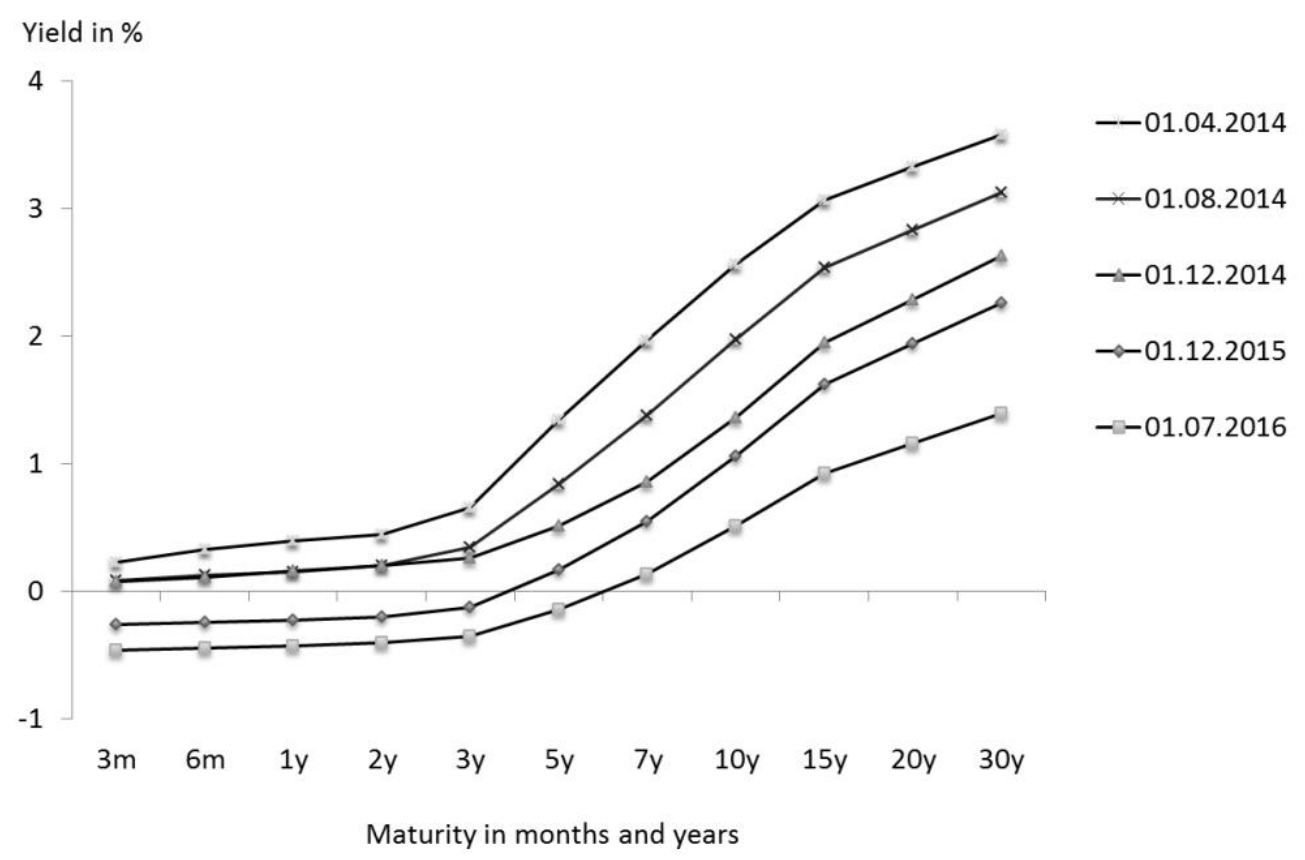

Note: Curves represent snapshots taken on the dates indicated on the right-hand side. Source: ECB

As mentioned above (Forward Guidance and QE in the Euro Area), the ECB has been buying government bonds with average remaining maturities of eight years. Due to their greater scarcity, the prices of bonds at these and other maturities rise, while yields fall. It is through this mechanism that QE 'bends' the long end of the yield curve. Figure 1 shows how the term structure of interest rates has shifted for government bonds in the euro area. While shifts of the yield curve cannot be attributed to monetary policy alone, the disproportionate compression of interest rates at the long end of the yield curve from 2014 onwards suggests that the ECB's twin policies of forward guidance and QE achieved the desired effect. According to the logic of the portfolio rebalancing channel, this compression sets off a 'search for yield' among investors, who move out of low-risk securities into higher risk assets, such as corporate bonds, equities, or loans to firms and households (Cœuré 2015, 2). In addition, the balance sheets of the owners of securities are strengthened as a result of rising financial asset prices. ${ }^{7}$

In short, central bank security purchases mechanically increase demand-and thus the price-for certain financial assets. While forward guidance has revealed the limitations of performative macroeconomic agency, QE has provided central banks with a hydraulic tool akin to fiscal policy: whereas government spending on goods and services increases firm revenues and household incomes, central bank spending on asset purchases is expected to increase financial firms' revenues and bolster their balance sheets.

${ }^{7}$ For a succinct discussion of QE transmission channels, see Haldane et al. (2017, 7-9). 


\section{Conclusion}

This chapter has argued that the performative nature of central banking has deeper roots in macroeconomic theory than has been acknowledged in the literature. While prominent economists have criticized the rational expectations hypothesis and DSGE models as 'figments' and as 'post-real' (Frydman and Goldberg 2011; Romer 2017), the performative consequences of these theoretical innovations have been real enough. What options traders did for the efficient market hypothesis, central bankers did for the rational expectations hypothesis. As a result, two key features of the 'model world' (Watson 2014)-'communism of models' and non-market price setting-gained a foothold in the real world.

Focussing primarily on the euro area, the chapter has highlighted the complementary nature of forward guidance and quantitative easing, both of which are geared towards bringing longer-term interest rates under central bank control. Deploying these policies to bend the yield curve, the ECB has incurred significant costs. Adding to the finding of a loss of monetary trust among the general public (Braun 2016b), the chapter has highlighted the loss of epistemic authority with financial market actors, who have voiced doubts regarding both the quality and the sincerity of the ECB's economic forecasts. This weakening of the performative dimension of central bank agency has been compensated, to a certain extent, by quantitative easing. From a conceptual perspective, QE constitutes a monetary version-updated for the conditions of a financialized economy-of the hydraulic macroeconomic agency that used to be the hallmark of Keynesian fiscal demand management.

Accounting for the costs and benefits of this hydraulic turn in monetary governance remains a major task for students of central banking. One of the key questions concerns the distributional consequences of large-scale asset purchase programmes. It remains unclear whether the wealth inequality-increasing consequences of asset price inflation-which are well documented-are compensated by the income inequality-decreasing stimulus effect of asset purchases on GDP growth and employment (ECB 2017, 48-51; Fontan et al. 2016).

The other big outstanding question concerns the governability consequences of central (bank) planning. In the 1980s, when central banks still cloaked themselves in obscurity, their justification echoed the Hayekian argument that uncertainty, by virtue of creating expectational diversity, actually has a stabilizing effect. One FOMC member feared that openness about the Fed's intentions would cause the market to 'move with a single purpose based on accurate knowledge of the short run objectives of the market's largest participant, the FOMC' (Goodfriend 1986, 77). With forward guidance and quantitative easing, bringing about this 'single purpose' has become a key plank of monetary policy. The price tag of non-market price setting via unconventional monetary policy therefore includes the loss of informational content in financial asset prices. Once a barometer of the decentralized beliefs and actions of myriad market actors, the long-term interest rate has become a policy variable, manipulated by central banks to reduce the 'perceived downside risk' for investors (BIS 2013, 1). The potential costs are manifoldincreased risk-taking, indebtedness, collateral scarcity, and financial instability, to name but a few. It remains to be seen if bending and de-risking the yield curve will make the future less uncertain. 


\section{References}

Abolafia, Mitchel Y., and Deneen M. Hatmaker. 2013. 'Fine-Tuning the Signal: Image and Identity at the Federal Reserve'. International Public Management Journal 16 (4): pp. 532556.

Atkins, Ralph. 2014. 'Draghi Performs Another Euro Conjuring Trick'. Financial Times, 9 May. Accessed 30 January 2017. http://www.ft.com/cms/s/o/450424ec-d77f-11e3-80eoo0144feabdco.html?siteedition=uk - axzz3BMMYBWgO.

Auer, Raphael, Claudio Borio, and Andrew Filardo. 2017. 'The Globalisation of Inflation: the Growing Importance of Global Value Chains'. BIS Working Paper 602. Basel: Bank for International Settlements.

Baker, Andrew, and Wesley Widmaier. 2014. 'The Institutionalist Roots of Macroprudential Ideas: Veblen and Galbraith on Regulation, Policy Success and Overconfidence'. New Political Economy 19 (4): 487-506.

Barro, Robert J., and David B. Gordon. 1983. 'Rules, Discretion and Reputation in a Model of Monetary Policy'. Journal of Monetary Economics 12 (1): pp. 101-121.

Beckert, Jens. 2013a. 'Capitalism as a System of Expectations: Toward a Sociological Microfoundation of Political Economy'. Politics \& Society 41 (3): pp. 323-350.

Beckert, Jens. 2013b. 'Imagined Futures: Fictional Expectations in the Economy'. Theory \& Society 42 (3): pp. 219-240.

Beckert, Jens. 2016. Imagined Futures: Fictional Expectations and Capitalist Dynamics. Cambridge, MA: Harvard University Press.

Bini Smaghi, Lorenzo. 2013. 'Why Forward Guidance has Failed to Convince'. Financial Times, 10 September. Accessed 30 January 2017. https://www.ft.com/content/74a2ac46-bd75-3117a $411-f c 777 f 5 f 2 d 6 f$.

BIS. 2013. 'Markets Grow Confident on Continued Support'. Bank of International Settlements Quarterly Review (March): pp. 1-13.

BIS. 2016. 86th Annual Report. Basel: Bank of International Settlements.

Blinder, Alan S. 2000. 'Central-Bank Credibility: Why Do We Care? How Do We Build It?' The American Economic Review 90 (5): pp. 1421-1431.

Blinder, Alan S. 2004. The Quiet Revolution. Central Banking Goes Modern. New Haven: Yale University Press.

Boldyrev, Ivan, and Olessia Kirtchik. 2016. 'The Cultures of Mathematical Economics in the Postwar Soviet Union: More than a Method, Less than a Discipline'. Studies in History and Philosophy of Science Part A 23 (1): pp. 38-56.

Borio, Claudio, and Piti Disyatat. 2009. Unconventional Monetary Policies: An Appraisal. BIS Working Paper no. 292, Bank of for International Settlements.

Borio, Claudio, and Haibin Zhu. 2012. 'Capital Regulation, Risk-Taking and Monetary Policy: A Missing Link in the Transmission Mechanism?' Journal of Financial Stability 8 (4): pp. 236251.

Braun, Benjamin. 2014. 'Why Models Matter: The Making and Unmaking of Governability in Macroeconomic Discourse'. Journal of Critical Globalisation Studies 7: pp. 48-79.

Braun, Benjamin. 2015. 'Governing the future: The European Central Bank's expectation management during the Great Moderation'. Economy and Society 44 (3): pp. 367-391.

Braun, Benjamin. 2016a. 'From Performativity to Political Economy: Index Investing, ETFs and Asset Manager Capitalism'. New Political Economy 21 (3): pp. 257-273.

Braun, Benjamin. 2016b. 'Speaking to the People? Money, Trust, and Central Bank Legitimacy in the Age of Quantitative Easing'. Review of International Political Economy 23 (6): pp. 10641092.

Bronk, Richard. 2011. 'Uncertainty, Modelling Monocultures and the Financial Crisis'. Business Economist 42 (2): pp. 5-18.

Bronk, Richard. 2013. 'Hayek on the Wisdom of Prices: A Reassessment'. Erasmus Journal for Philosophy and Economics 6 (1): pp. 82-107.

Bronk, Richard, and Wade Jacoby. 2016. 'Uncertainty and the Dangers of Monocultures in Regulation, Analysis, and Practice'. MPIfG Discussion Paper 16/6, Cologne: Max Planck Institute for the Study of Societies. 
Buiter, Willem. 2013. 'Forward Guidance: More than Old Wine in New Bottles and Cheap Talk?'. Citi Global Economic View, Citigroup Global Markets.

Caballero, Ricardo J. 2010. 'Macroeconomics after the Crisis: Time to Deal with the Pretense-ofKnowledge Syndrome'. Journal of Economic Perspectives 24 (4): pp. 85-102.

Campbell, Jeffrey R., Charles L. Evans, Jonas D. M. Fisher, Alejandro Justinianio, Charles W. Calomiris, and Michael Woodford. 2012. 'Macroeconomic Effects of Federal Reserve Forward Guidance'. Brookings Papers on Economic Activity (Spring 2012): pp. 1-80.

Christophers, Brett. 2017. 'The Performativity of the Yield Curve'. Journal of Cultural Economy 10 (1): pp. 63-80.

Couré, Benoît. 2015. Embarking on Public Sector Asset Purchases. Speech at the Second International Conference on Sovereign Bond Markets, Frankfurt, 10 March.

Conti-Brown, Peter. 2016. The Power and Independence of the Federal Reserve. Princeton: Princeton University Press.

Draghi, Mario. 2013. Introductory Statement to the Press Conference, 4 July. http://www.ecb.europa.eu/press/pressconf/2013/html/is130704.en.html.

Draghi, Mario. 2015. Introductory Statement to the Press Conference, 22 January. http://www.ecb.europa.eu/press/pressconf/2015/html/is150122.en.html.

ECB. 2008. The Analysis of the Euro Money Market from a Monetary Policy Perspective. Monthly Bulletin (February): pp. 65-79.

ECB. 2010. Monetary Policy Transmission in the Euro Area, a Decade After the Introduction of the Euro. Monthly Bulletin (May): pp. 85-98.

ECB. 2014. The ECB's Forward Guidance. Monthly Bulletin (April): pp. 65-73.

ECB. 2017. Annual Report 2016. Frankfurt: European Central Bank.

Evans, George W., and Seppo Honkapohja. 2005. 'An Interview With Thomas J. Sargent'. Macroeconomic Dynamics 9 (4): pp. 561-583.

Filardo, Andrew, and Boris Hofmann. 2014. 'Forward Guidance at the Zero Lower Bound'. BIS Quarterly Review (March): pp. 37-53.

FOMC. 2013. FOMC Meeting Statement, 18 December 2013. http://www.federalreserve.gov/newsevents/press/monetary/20131218a.htm.

Fontan, Clément, François Claveau, and Peter Dietsch. 2016. 'Central Banking and Inequalities: Taking Off the Blinders'. Politics, Philosophy \& Economics 15 (4): 319-357.

Friedman, Benjamin. 2014. 'Has the Financial Crisis Permanently Changed the Practice of Monetary Policy? Has It Changed the Theory of Monetary Policy?'. NBER Working Paper no. 20128, Cambridge, MA: National Bureau of Economic Research.

Frydman, Roman, and Michael D. Goldberg. 2011. Beyond Mechanical Markets: Asset Price Swings, Risk, and the Role of the State. Princeton, NJ: Princeton University Press.

Gabor, Daniela, and Bob Jessop. 2015. 'Mark my words: Discursive Central Banking in Crisis'. In Financial Cultures and Crisis Dynamics, edited by Bob Jessop, Brigitte Young and Christoph Scherrer, pp. 294-315. London: Routledge.

Giddens, Anthony. 1987. 'Social Theory and Problems of Macroeconomics'. In Social Theory and Modern Sociology, edited by Anthony Giddens, pp. 183-202. Cambridge: Polity Press.

Goffman, Erving. 1959. The Presentation of Self in Everyday Life. Garden City, NY: Double Day.

Golub, Stephen, Ayse Kaya, and Michael Reay. 2015. 'What Were They Thinking? The Federal Reserve in the Run-Up to the 2008 Financial Crisis'. Review of International Political Economy 22 (4): pp. 657-692.

Goodfriend, Marvin. 1986. 'Monetary Mystique: Secrecy and Central Banking'. Journal of Monetary Economics 17 (1): pp. 63-92.

Goodhart, Charles. 2012. 'Longer-Term Forecasts Are a Step Backwards'. Financial Times, 1 February. Accessed 30 January 2017. http://www.ft.com/intl/cms/s/o/2034b62a-4coo-11e1b1b5-00144feabdco.html - axzz3dn5Evkg2.

Gramsci, Antonio. 1971. Selections from the Prison Notebooks of Antonio Gramsci. Edited and translated by Quintin Hoare and Geoffrey Nowell Smith. London: Lawrence \& Wishart.

Haldane, Andrew G. 1995. 'Rules, Discretion and the United Kingdom's New Monetary Framework'. Working Paper, London: Bank of England.

Haldane, Andrew G. 2017. 'A Little More Conversation, A Little Less Action'. Speech at the Macroeconomics and Monetary Policy Conference, Federal Reserve Bank of San Francisco, 31 March. 
Haldane, Andrew G., Matt Roberts-Sklar, Tomasz Wieladek, and Chris Young. 2017. 'QE - the story so far'. Staff Working Paper 624, London: Bank of England.

Hall, Peter A. 1993. 'Policy Paradigms, Social Learning, and the State: The Case of Economic Policymaking in Britain'. Comparative Politics 25 (3): pp. 275-96.

Hayek, Friedrich A. 1945. 'The Use of Knowledge in Society'. The American Economic Review 35 (4): pp. 519-30.

Hayek, Friedrich A. 1989. 'The Pretence of Knowledge (Nobel Lecture 1974)'. The American Economic Review 79 (6): pp. 3-7.

Heimberger, Philipp, and Jakob Kapeller. 2017. 'The Performativity of Potential Output: ProCyclicality and Path Dependency in Coordinating European Fiscal Policies'. Review of International Political Economy 24(5): pp. 904-928.

Holmes, Douglas R. 2014. Economy of Words. Communicative Imperatives in Central Banks. Chicago: Chicago University Press.

Issing, Otmar. 1992. 'Theoretical and Empirical Foundations of the Deutsche Bundesbank's Monetary Targeting'. Intereconomics 27 (6): pp. 289-300.

Issing, Otmar. 2014. 'Forward Guidance: A New Challenge for Central Banks'. SAFE White Paper Series no. 16, Frankfurt: Sustainable Architecture for Finance in Europe.

Juselius, Mikael, Claudio Borio, Piti Disyatat, and Mathias Drehmann. 2016. 'Monetary Policy, the Financial Cycle, and Ultralow Interest Rates'. Discussion Paper 24/16, Bank of Finland.

Konings, Martijn. 2016. 'Governing the System: Risk, Finance, and Neoliberal Reason'. European Journal of International Relations 22 (2): pp. 268-288.

Krippner, Greta R. 2007. 'The Making of US Monetary Policy: Central Bank Transparency and the Neoliberal Dilemma'. Theory and Society 36 (6): 477-513.

Kydland, Finn E., and Edward C. Prescott. 1977. 'Rules Rather than Discretion: The Inconsistency of Optimal Plans'. The Journal of Political Economy 85 (3): pp. 473-491.

Lucas, Robert E., and Thomas J. Sargent. 1979. 'After Keynesian Macroeconomics'. Quarterly Review 3 (2): pp. 49-72.

MacKenzie, Donald. 2006. An Engine, Not a Camera: How Financial Models Shape Markets. Cambridge, MA: MIT Press.

Mackintosh, James. 2014. 'ECB Left to Ponder Onset of Stealth Tightening'. Financial Times, 4 March. Accessed 30 January 2017. http://www.ft.com/cms/s/o/cao22222-a3c5-11e3-aa85o0144feab7de.html?siteedition=uk - axzz39vUAgl99.

Marcussen, Martin. 2009. 'Scientization of Central Banking: The Politics of A-Politicization'. In Central Banks in the Age of the Euro. Europeanization, Convergence, and Power, edited by Kenneth Dyson and Martin Marcussen, pp. 373-90. Oxford: Oxford University Press.

Mirowski, Philip. 2002. Machine Dreams: Economics Becomes a Cyborg Science. Cambridge: Cambridge University Press.

Mitchell, Timothy. 2005. 'The Work of Economics: How a Discipline Makes Its World'. European Journal of Sociology 46 (2): pp. 297-320.

Morris, Stephen, and Hyun Song Shin. 2002. 'Social Value of Public Information'. The American Economic Review 92 (5): pp. 1521-1534.

Morris, Stephen, and Hyun Song Shin. 2008. 'Coordinating Expectations in Monetary Policy'. In Central Banks as Economic Institutions, edited by Jean-Philippe Touffut, pp. 88-104. Cheltenham: Edward Elgar.

Mudge, Stephanie L., and Antoine Vauchez. 2016. 'Fielding Supranationalism: the European Central Bank as a Field Effect'. The Sociological Review Monographs 64 (2): 146-169.

Muth, John F. 1961. 'Rational Expectations and the Theory of Price Movements'. Econometrica 29 (3): pp. 315-335.

Nelson, Stephen C., and Peter J. Katzenstein. 2014. 'Uncertainty, Risk, and the Financial Crisis of 2008'. International Organization 68 (2): pp. 361-392.

Pahl, Hanno, and Jan Sparsam. 2016. 'The IS-LMization of the General Theory and the Construction of Hydraulic Governability in Postwar Keynesian Macroeconomics'. In Enacting Dismal Science, edited by Ivan Boldyrev and Ekaterina Svetlova, 151-181. New York: Palgrave Macmillan US.

Poole, William, and Robert H. Rasche. 2000. 'Perfecting the Market's Knowledge of Monetary Policy'. Journal of Financial Services Research 18 (2): 255-98. 
Praet, Peter. 2014. 'Current Issues and Challenges for Central Bank Communication'. Speech at the ECB and its Watchers XV, Frankfurt, 12 March.

Romer, Paul. 2017. 'The Trouble with Macroeconomics'. The American Economist, forthcoming.

Rosenhek, Zeev. 2013. 'Diagnosing and Explaining the Global Financial Crisis: Central Banks, Epistemic Authority, and Sense Making'. International Journal of Politics, Culture, and Society 26 (3): pp. 255-72.

Shin, Hyun Song. 2017. 'How Much Should we Read Into Shifts in Long-Dated Yields?'. Speech at the US Monetary Policy Forum, New York City, 3 March.

Turner, Philip. 2011. 'Is the Long-Term Interest Rate a Policy Victim, a Policy Variable or a Policy Lodestar?' BIS Working Paper no. 367, Basel: Bank for International Settlements.

Valiante, Diego. 2016. 'The "Visible Hand” of the ECB's first Quantitative Easing'. International Economics and Economic Policy, Online First Article.

Watson, Matthew. 2014. Uneconomic Economics and the Crisis of the Model World. London: Palgrave Macmillan.

Widmaier, Wesley W. 2016. Economic Ideas in Political Time. Cambridge: Cambridge University Press.

Woodford, Michael. 2003. Interest and Prices. Foundations of a Theory of Monetary Policy. Princeton, NJ: Princeton University Press.

Woodford, Michael. 2009. 'Convergence in Macroeconomics: Elements of the New Synthesis'. American Economic Journal: Macroeconomics 1 (1): 267-79.

Woodford, Michael. 2014. 'Forward Guidance by Inflation-Targeting Central Banks'. CEPR Discussion Paper no. 9722, London: Centre for Economic Policy Research. 